\title{
Thyroid-stimulating hormone receptor (TSHR) fusion proteins in Graves' disease
}

\author{
Hans-Peter Holthoff1,*, Kerstin Uhland ${ }^{1, *}$, Gabor Laszlo Kovacs ${ }^{2}$, Andreas Reimann ${ }^{1}$, Kristin Adler $^{1}$, Clara Wenhart ${ }^{1}$ \\ and Martin Ungerer ${ }^{1}$
}

1 Procorde - advancecor, Martinsried, Germany

21st Department of Internal Medicine, Flor Ferenc Hospital, Kistarcsa, Hungary

Correspondence should be addressed to M Ungerer: ungerer@procorde.com

*(H-P Holthoff and K Uhland contributed equally to this work)

\begin{abstract}
Graves' disease is an autoimmune disorder, which is characterized by stimulatory antibodies targeting the human thyrotropin receptor (TSHR), resulting in hyperthyroidism and multiple organ damage. We systematically investigated monomeric and dimeric fusion proteins of the A subunit of TSHR for efficacy to bind to the monoclonal patient antibody M22, to interact with Graves' patient serum samples, and to impact on anti-TSHR antibody titers, hyperthyroidism, tachycardia and other in vivo readouts in a long-term mouse model of Graves' disease induced by immunization with a recombinant adenovirus encoding TSHR A. Binding assays and functional measurements of TSHR-dependent CAMP formation showed binding of monomeric TSHR-His and dimeric TSHR-Fc to the anti-TSHR antibody M22 at low-effective concentrations ( $\mathrm{EC}_{50}$ of $5.7 \mathrm{nmol} / \mathrm{L}$ and $8.6 \mathrm{nmol} / \mathrm{L}$ ) and inhibition of the effects of this antibody at high efficiencies $\left(\mathrm{IC}_{50}\right.$ values of $\left.16-20 \mathrm{nmol} / \mathrm{L}\right)$. Both proteins also block the effects of polyclonal anti-TSHR antibodies occurring in Graves' patient sera with somewhat lower average efficiencies (mean $\mathrm{IC}_{50}$ values of $29 \mathrm{nmol} / \mathrm{L}$ and $68 \mathrm{nmol} / \mathrm{L}$ ). However, in vivo characterization of epicutaneous patch administrations of TSHR-Fc at doses of 0.3 and $0.6 \mathrm{mg} / \mathrm{kg}$ body weight in a murine Graves' disease model did not result in any improvement of disease parameters. In conclusion, high affinity binding of TSHR-Fc to pathological anti-TSHR antibodies was not matched by efficacy to improve Graves' disease parameter in a long-term mouse model.
\end{abstract}

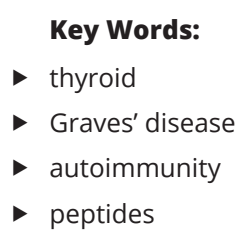

Journal of Endocrinology (2020) 246, 135-147

\section{Introduction}

In patients with Graves' disease (GD), antibodies which target the thyrotropin-TSH receptor (TSHR) in the thyroid gland and other autoimmune markers are observed. This autoimmune condition results in hyperthyroidism (Weetman 2000, Smith \& Hegedüs 2016), with an annual incidence of $20-80$ per 100,000 persons throughout the world. If left untreated, Graves' leads to significantly increased morbidity and mortality (Ross 2011). Graves' orbitopathy afflicts about $50 \%$ of patients and is especially hard to treat (Bahn 2010).

Despite the central role for the TSH holoreceptor (TSHR) in increasing thyroid hormone synthesis and secretion after ligand binding, strong experimental evidence suggests that it is not the holoreceptor but the 
A-subunit, a shed component of the extracellular domain, that is the primary immunogen in the induction and affinity maturation of pathologic stimulating anti-TSHR antibodies (Chen et al. 2003, Mizutori et al. 2009).

Preparations of the secreted TSHR ectodomain variant TSHR-289, essentially the TSHR A-subunit, contained two different forms, with reciprocally exclusive binding characteristics to anti-TSHR autoantibodies. The temperature-sensitive form (also termed 'immunologically active' by the group of Rapoport and colleagues) neutralized the TSHR binding, stimulatory activity of Graves' sera, whereas the temperature-insensitive form (also termed 'inactive') was not reactive with sera from Graves' patients (Chazenbalk et al. 1999, 2001, Schwarz-Lauer et al. 2002, Miller-Gallacher et al. 2019). In contrast, the temperatureinsensitive form was bound by the murine monoclonal anti-TSHR antibody 3BD10 which did not bind to the temperature-sensitive A-subunit in the preparation (Chazenbalk et al. 1999, 2001, Schwarz-Lauer et al. 2002). The human Graves' patient-derived monoclonal antiTSHR antibody M22 was shown to bind specifically to the temperature-sensitive TSHR A-subunit (Chazenbalk et al. 1999, Hamidi et al. 2013, Rapoport et al. 2015).

The temperature-sensitive A-subunit has been shown to be unstable at $37^{\circ} \mathrm{C}$. At this temperature it transforms into the temperature-insensitive A-subunit within 1-7 h, depending on the presence of stabilizing agents in the medium (Chazenbalk et al. 1999, 2001, Schwarz-Lauer et al. 2002). In contrast, at ambient temperature and at $27^{\circ} \mathrm{C}$, the temperature-sensitive A-subunit is stable. In previous studies, the binding specificity of 3BD10 to the temperature-insensitive TSHR A-subunit had been used to separate the two TSHR A-subunits after recombinant expression, that is, the temperature-insensitive form was removed from the preparation by affinity chromatography with 3BD10, leaving the isolated temperature-sensitive form.

The temperature sensitivity was assimilated in a protocol for efficient recombinant expression of a tagged protein of temperature-sensitive extracellular TSHR domain (aa 21-261) and alkaline phosphatase (used as a molecular probe to directly detect the binding of antiTSHR antibodies from patient samples in a bridging ELISA) by secretion of the molecules for $24 \mathrm{~h}$ at $27^{\circ} \mathrm{C}$ (Frank et al. 2015). This manuscript describes that we reconfirmed this protocol and produced temperature-sensitive forms of the TSHR A-subunit by transferring the expression cell lines to $27^{\circ} \mathrm{C}$.

We then wished to characterize temperature-sensitive forms of a His-tagged TSHR A domain, as well as of a Fc fusion protein of this TSHR domain, which expresses two of these domains per molecule, in several assays including Graves' disease patient blood samples ex vivo. In addition, we investigated the capacity of the Fc fusion protein to mitigate disease parameters in a long-term mouse model of the disease. Previously, we had described this longterm disease model for human Graves' disease with nine immunizations of recombinant adenovirus expressing the extracellular A subunit of the TSHR (Holthoff et al. 2015) to permanently boost antibody production in mice. The TSHR A domain variants were tested for their potency to impact on long-term disease parameters in TSHR-immunized mice, such as hyperthyroidism (T4 values), thyroid size and tachycardia. A pivotal previous study had shown that while pre-administration of TSHR A domain attenuated the induction of hyperthyroidism by subsequent immunization with the TSHR A domain adenovirus by diverting the antibody response, s.c. injection of TSHRA domain was ineffective when administered once after disease induction in a short-term model (Misharin et al. 2009, observation for 5 weeks after single therapy). Since i.v. administration of TSHR-Fc led to signs of allergy and slight anti-TSHR antibody titer elevations in the long-term mouse model (Holthoff et al. 2017), we wished to investigate repeated epicutaneous/ transdermal application instead, as has been proposed in several studies on other autoimmune diseases such as multiple sclerosis in preclinical and clinical studies (Bynoe et al. 2003, Walczak et al. 2013, Wildner \& Selmaj 2017). Antigen-specific approaches may target anti-TSHR antibodies directly, or respective specific B cell receptors, or epidermal Langerhans cells, which then typically present the antigen to further immune cells. In this study, we only chose TSHR-Fc for in vivo experiments, since their purification is easiest, and epicutaneous antigen administration presumably favors presentation of processed peptides by Langerhans cells to T cells, and the amino acid sequence of TSHR is the same in TSHR-Fc or TSHR-His.

\section{Materials and methods}

\section{Human serum samples}

Serum samples from 48 patients with suspected GD were taken at Flor Ferenc Hospital, Kistarcsa, Hungary. This study was approved by the Hungarian Ethics Committee at Budapest (Egeszsegügyi Tudomanyos Tanacs), which issued an independent ethics vote 7022/2016/EKU (0102/16) on February 24, 2016. 
The principles of the Declaration of Helsinki were respected. Consent has been obtained from each patient or subject after full explanation of the purpose and nature of all procedures used.

All patients had clinical signs of hyperthyroidism. Mean subject age was 38.8 \pm 13.7 and the female/male proportion was $77 \%$ female, 23\% male. Most patients with GD had been medically treated with antithyroid drugs.

Serum samples from 17 healthy volunteers served as controls.

\section{Cloning, transfection, production, and purification of human TSHR-His}

\section{Generation of a CHO TSHR289 His cell line}

TSHR-His consists of the first 289 amino acids of the human TSHR (extracellular TSHR A subunit) followed by a Factor Xa cleavage site and six histidines. The cDNA sequence adapted for hamster codon usage was produced synthetically by GeneArt (Life Technologies) and cloned into the plasmid vector pcDNA5/FRT via HindIII and XhoI. The resulting expression vector was transfected into Flp-In ${ }^{\mathrm{TM}}$-Chinese hamster ovary $(\mathrm{CHO})$ cells (Life Technologies), together with the plasmid pOG44, providing site-directed recombination. After selection of a stably expressing clone in Ham's F12 supplemented with $10 \%$ fetal bovine serum and $600 \mu \mathrm{g} / \mathrm{mL}$ Hygromycin $\mathrm{B}$, the clone was adapted to ProCHO5 medium (Lonza, \#BE12-766Q) supplemented with $4 \mathrm{mM}$ L-glutamine (Biochrom, Cambridge, UK; \#K0283).

The resulting vector was called pcDNA5/FRT-TSHR-His and allows expression and secretion of TSHR-His into the culture medium of mammalian cells under the control of the human cytomegalovirus (CMV) immediate-early enhancer/promoter and selection for stable clones with Hygromycin B after co-transfection with plasmid pOG44.

\section{Expression and purification of temperature-sensitive and temperature-insensitive TSHR-His}

For the expression of TSHR-His, CHO-TSHR289-His cells were grown in ProCHO5, $4 \mathrm{mM}$ L-glutamine in flasks to submaximal density at $37^{\circ} \mathrm{C}$ and then centrifuged. For expression of the temperature-sensitive TSHR-His, the cell pellet was resuspended in one-third of the original volume of the medium and incubated for $24 \mathrm{~h}$ at $27^{\circ} \mathrm{C}$. For the expression of temperature-insensitive TSHR-His, the cells were continuously grown at $37^{\circ} \mathrm{C}$. The supernatants were cleared by centrifugation at $4000 \boldsymbol{g}$ for $10 \mathrm{~min}$ and subsequent filtration with a $0.22 \mathrm{~nm}$ sterile filter (TPP, Trasadingen, Switzerland; \#99722). The resulting
TSHR A subunit containing medium was immediately frozen and stored at $-80^{\circ} \mathrm{C}$ until protein purification. The supernatants from the $37^{\circ} \mathrm{C}$ and $27^{\circ} \mathrm{C}$ cell cultures were used for the preparations of TSHR-His containing more temperature-insensitive and temperature-sensitive TSHR-His, respectively.

For protein purification, thawed CHO-TSHR289-His supernatants were diluted 1:4 in $20 \mathrm{mM}$ sodium phosphate, $0.5 \mathrm{M} \mathrm{NaCl}, \mathrm{pH} 7.4$, and loaded on an equilibrated $1 \mathrm{~mL}$ HisTrap ${ }^{\mathrm{TM}}$ excel column (GE Healthcare 17-3712-05). After washing the column with $20 \mathrm{mM}$ sodium phosphate, $0.5 \mathrm{M}$ $\mathrm{NaCl}$, pH 7.4, TSHR-His was eluted with $4 \times 0.5 \mathrm{~mL} 20 \mathrm{mM}$ sodium phosphate, $0.333 \mathrm{M} \mathrm{NaCl}, 0.333 \mathrm{mM}$ imidazole, $\mathrm{pH}$ 7.4. Protein content was determined by OD 280 measurement and the relevant fractions were dialysed (Slyde-A-Lyzer Dialysis Cassette, 10000 MWCO, Thermo Scientific \# 66380) against PBS at $4^{\circ} \mathrm{C}$ for $16 \mathrm{~h}$.

\section{Expression and purification of the TSHR A subunit-Fc fusion protein}

The fusion protein TSHR-Fc consisting of the first 289 amino acids of the human TSHR followed by a GGR linker and the Fc portion of human immunoglobulin $\mathrm{G}$ (IgG) 2 was produced based on what was previously described (Holthoff et al. 2017). However, in that study a predominantly temperature-sensitive form was produced in ProCHO5, $4 \mathrm{mM}$ L-glutamine in flasks instead of spinner culture, and culture was performed at $27^{\circ} \mathrm{C}$ instead of $37^{\circ} \mathrm{C}$.

\section{Measurement of human anti-TSHR antibodies by competitive sandwich ELISA}

All procedures were performed at room temperature (RT) and incubations were on a microtiter plate shaker. ELISA plates were coated with $100 \mu \mathrm{L} /$ well well-characterized, high-affinity monoclonal anti TSHR antibody M22 (RSR Limited, Cardiff, UK) in coating solution for $1 \mathrm{~h}$. The coated plates were washed three times with PBST (PBS, $0.1 \%$ Tween-20), blocked with $100 \mu \mathrm{L} /$ well of blocking solution (PBST, 3\% milk powder) for $1 \mathrm{~h}$, and washed again. Either $6 \mu \mathrm{L} /$ well serum sample $+24 \mu \mathrm{L}$ PBST or $30 \mu \mathrm{L}$ standard solution (spiked with human serum received from third generation ELISA kit, RSR Limited), respectively, was mixed with $30 \mu \mathrm{L} /$ well of $2 \mu \mathrm{g} / \mathrm{mL}$ temperature-sensitive TSHR-His or TSHR-Fc in a dilution plate and incubated for $0.5 \mathrm{~h}$. Afterwards the different mixes were transferred to the blocked ELISA plates and incubated for $1 \mathrm{~h}$. After washing with PBST, the ELISA plates were incubated for $1 \mathrm{~h}$ either (for TSHR-His) with 
$100 \mu \mathrm{L} /$ well of the anti-His detection antibody labeled with POD (Bethyl, Montgomery, TX, USA; \#A190-114P, 1:3000 dilution in PBST) or (for TSHR-Fc) with polyclonal anti-TSHR antibodies from Ad-TSHR-immunized mice followed by POD-labelled anti-mouse Fc Fab antibodies (Jackson \#115-036-072). After washing, bound POD was detected by incubation with $100 \mu \mathrm{L} /$ well of $\mathrm{TMB}$ substrate (Thermo Scientific, \#34029) until a maximal optical density (OD) of about 1-2 was reached. Finally, the colorimetric reaction was stopped with $100 \mu \mathrm{L} /$ well stopping solution $\left(1 \mathrm{M} \mathrm{H}_{2} \mathrm{SO}_{4}\right)$ and the $\mathrm{OD}$ determined at a wavelength of $450 \mathrm{~nm}$ with a reference wave length of $595 \mathrm{~nm}$ with in a plate reader. The binding of TSHR subunit A-His and TSHR-Fc to coated M22 was analyzed with the same procedure, however, with varying concentrations of protein and without pre-incubation with serum or antiTSHR antibody.

\section{Determination of stimulatory anti-TSHR antibodies with the cAMP assay}

TSHR-stimulating antibodies in the serum of Graves' disease patients were analyzed by measuring cyclic AMP (cAMP) generation in CHO cells JP2626 expressing the human TSHR (kindly provided by Dr Gilbert Vassart, Brussels, Belgium). CHO cells were seeded into 96-well plates (30,000 cells per well) and incubated for $24 \mathrm{~h}$ in Dulbecco's modified Eagle medium (DMEM, Invitrogen Ltd) containing $2 \%$ fetal calf serum. Then, DMEM was removed and human serum was diluted 1:5 in $50 \mu \mathrm{L}$ HBSS buffer (20 mM Hepes, $1.26 \mathrm{mM} \mathrm{CaCl}_{2}, 5.33 \mathrm{mM}$ $\mathrm{KCl}, 0.44 \mathrm{mM} \mathrm{KH}_{2} \mathrm{PO}_{4}, 0.5 \mathrm{mM} \mathrm{MgCl}, 0.4 \mathrm{mM} \mathrm{MgSO}_{4}$, $4.2 \mathrm{mM} \mathrm{NaHCO}_{3}, 5.6 \mathrm{mM}$ glucose, and $222 \mathrm{mM}$ sucrose, $\mathrm{pH}$ 7.2) supplemented with $1.5 \%$ BSA and $0.5 \mathrm{mM}$ isobutyl-1-methylxanthine (Sigma-Aldrich) and added to each well. After incubation for $2.5 \mathrm{~h}$ at $37^{\circ} \mathrm{C}$ the cAMP release in the medium was measured in duplicates by a competitive ELISA (\#EMSCAMPL, Thermo Fisher Scientific).

\section{Determination of anti TSHR antibodies with the third-generation assay}

Human antibodies against TSHR were detected by a commercially available TSH receptor autoantibody third-generation enzyme immunoassay (\# TRE/96/3A) provided by RSR Limited, in which the human Graves patient-derived M22 MAB and serum antibodies compete for binding sites on immobilized TSHR. The assay was performed using $30 \mu \mathrm{L}$ (instead of $75 \mu \mathrm{L}$ ) human serum in at least duplicate determination according to the manufacturer's instructions.

\section{Multimer analysis by sedimentation velocity ultracentrifugation}

In order to compare the quarternary structure of stressed and unstressed TSHR-Fc, an aliquot of $1.6 \mathrm{mg} / \mathrm{mL}$ TSHR-Fc was stressed by incubating the protein in PBS at $37^{\circ} \mathrm{C}$ for $24 \mathrm{~h}$. Stressed and unstressed TSHR-Fc were subjected to multimer analysis by sedimentation velocity ultracentrifugation which was carried out at Coriolis Pharma Research GmbH (Planegg, Germany). For SV-AUC measurements, samples were used at a concentration of $0.8 \mathrm{mg} / \mathrm{mL}$ (corresponding to -1 OD $280,1.2 \mathrm{~cm}$ in the AUC cell). Each sample was analyzed in triplicate in a ProteomeLab XL-I analytical ultracentrifuge (Beckman-Coulter) at $20^{\circ} \mathrm{C}$, by using an 8 -hole An-50 Ti analytical rotor and 12-mm epon-charcoal double-sector centerpieces with sapphire windows.

Of each sample, $340 \mu \mathrm{L}$ were loaded into the sample sector of the double-sector centerpiece, and $360 \mu \mathrm{L}$ of PBS into the reference sector in order to distinguish sample from buffer menisci. Prior to the measurement, sample concentrations and absence of leaks were confirmed at $3000 \mathrm{rpm}(1000 \boldsymbol{g})$, followed by at least $1 \mathrm{~h}$ of sample and rotor temperature equilibration with resting rotor. The evolution of sedimentation profiles at $35 \mathrm{k} \mathrm{rpm}$ $(102,700 \boldsymbol{g})$ was recorded by using absorbance optics in intensity mode at a wavelength of $280 \mathrm{~nm}$. Data analysis was performed with Sedfit (version 15.01b). Buffer density and viscosity values as well as the partial specific volume for the protein (based on the amino acid sequence) were estimated with UltraScan. By using Sedfit, SV-AUC raw data were pre-processed (meniscus position fixed, bottom position fit, and time-invariant and radially invariant noise correction) and analyzed by using the continuous c(s) distribution model (s range: 0-22 S) with Tikhonov maximum entropy regularization (confidence level: 0.95) for the assessment of continuous sedimentation coefficient c(s) distributions.

\section{Studies in immunized mice}

Recombinant adenovirus containing the DNA sequence of the first 289 amino acids of the human TSH receptor were used as described before (Holthoff et al. 2015). Female $\mathrm{BALB} / \mathrm{c}$ mice were delivered from Charles River and were adapted for at least 1 week to start experiments at the age of 6 weeks. Animals were kept under standard housing 
conditions $\left(23 \pm 2^{\circ} \mathrm{C}, 55 \pm 10 \% \mathrm{RH}\right)$ in groups of ten animals in GR1800DD cages (Tecniplast $®$ ). All animal experiments were approved by the local animal welfare authority and Ethics committee at the Regierung von Oberbayern (Government of Upper Bavaria) in Munich, Germany (no. 55.2-1-54-2531-25-12), and carried out in accordance to the World Medical Association (Declaration of Helsinki), and the European Commission guidelines (Directive 2010/63/EU). All guidelines for care of animals were respected.

\section{Immunizations}

Mice received $10^{10}$ plaque-forming units (pfu) of adenovirus carrying the A-subunit (AA 1-289) of the TSHR gene (Ad-TSHR289) or green fluorescent protein (Ad-GFP, immunized control). In addition, age-matched immunologically naïve mice which were not immunized and were not treated were studied for comparison as healthy control group. For immunization, mice were anaesthetized with isoflurane (introduction 5\%, maintenance $1.5-2 \%$ ) and placed on a heating pad. The adenovirus was injected into the left and right femoral muscles in a volume of $25 \mu \mathrm{L}$ each.

\section{Blood withdrawals}

For blood withdrawal, mice were moved to a restrainer. $100 \mu \mathrm{L}$ of blood was withdrawn out of the left or right tail vein with a $27 \mathrm{G}$ needle. Blood was centrifuged at $2400 \boldsymbol{g}$ for $15 \mathrm{~min}$ at room temperature and serum was stored at $-20^{\circ} \mathrm{C}$. At the end of the study (before euthanasia), blood was withdrawn intracardiacally in deep anesthesia (170 mg/kg ketamine $+17 \mathrm{mg} / \mathrm{kg}$ xylazine) with a $1 \mathrm{~mL}$ syringe and a $24 \mathrm{G}$ needle and treated as mentioned above.

The study protocol used three 3-weekly immunizations ('initiation'), followed by a maintenance phase with further regular 4-weekly boosts until the $9^{\text {th }}$ immunization, with either Ad-TSHR or control Ad-GFP (green fluorescent protein), as described before (Holthoff et al. 2015). Strict inclusion and exclusion criteria were defined before starting the study: If T4 thyroxin values in Ad-TSHR289-immunized mice were at least 25\% higher at week 11 compared to basal measurement at week 0 , mice were included for further study. Consequently, 25\% of immunized mice were excluded before randomization because they did not meet this threshold. Also, mean T4 values and basal heart rates of all groups had to be consistently altered. Remaining mice were randomly assigned to therapeutic groups, allocations were concealed, and veterinarians and all other staff who handled and analyzed the animals, were strictly blinded to the treatment groups.

\section{Drug administrations}

TSHR-Fc ( 0.3 or $0.6 \mathrm{mg} / \mathrm{kg}$ bw) or $0.9 \% \mathrm{NaCl}$ vehicle control were given 1 week after the $4^{\text {th }}$ immunization by epicutaneous patches over $24 \mathrm{~h}$ (Finn Chambers Aqua acquired from SmartPractice, Phoenix, AZ, USA, diameter: $8 \mathrm{~mm}$ ), after shaving mouse backs on a $2.5 \times 2.5 \mathrm{~cm}$ area. About $25 \mu \mathrm{L}$ of drug or vehicle solution were applied in each Finn Chamber, and due to small variations in pipetting and body weight of mice, we estimate dosing error at max. $\pm 8 \%$. This treatment was then repeated at 4-weekly intervals, as described before for i.v. peptide administrations (Holthoff et al. 2017). No animal was excluded after randomization.

\section{Determination of heart rate, ECG, and organ analysis}

When mice were subjected to anesthesia for immunization, their heart rate was monitored by an ECG (ECG amplifier module, Harvard Apparatus, Hugo Sachs Electronik, March, Germany) and recorded with a special software, which allows to determine the heart rate from the ECG reading (Haemodyn, Hugo Sachs Electronik). ECG was also performed in anesthesia before animals were killed for histological exam at the end of the study.

After killing, dissection and determination of the organ size of the thyroid glands was performed under a stereomicroscope, as described before (Holthoff et al. 2015).

\section{Measurements in mouse sera}

Total thyroxine (T4) was measured by using an immunoassay kit (\#T4044T-100, Calbiotech Inc, Austin, CA, USA) in duplicate determination.

Anti-TSHR autoantibody titers and potency of antibodies to stimulate TSHR-dependent cAMP levels in test cells were determined before start of immunisation (basal value), 56 days after the first immunisation, 133 days after the first immunisation, and 189 days after the first immunisation, and at the end of experiment. To this aim, a '3rd generation assay' was used: antibodies against TSHR were detected by a commercially available 3rd generation enzyme immunoassay provided by RSR Limited, as described above for human serum samples. The assay was performed using $30 \mu \mathrm{L}$ 1:10 (PBS) diluted serum in at least double determination.

\section{Calculations and statistical analysis}

All curves were fitted by SigmaPlot by using a 4-parameter logistic curve, which served to calculate $\mathrm{EC}_{50}$ and 
$\mathrm{IC}_{50}$ values. Mean $\mathrm{EC}_{50^{-}}$and $\mathrm{IC}_{50^{-}}$-values from several curves and corresponding CIs were calculated on the basis of decadic logarithms of concentration values. Results of in vivo experiments were compared by ANOVA when appropriate.

\section{Results}

\section{Characterization of the temperature-sensitive and -insensitive forms of TSHR-His}

\section{Expression and purification}

To provide the temperature-sensitive TSHR protein as ligand for human anti-TSHR antibodies and the temperature-insensitive form, $\mathrm{CHO}$ cells were stably transfected with the transgene expressing the his-tagged extracellular subunit A (1-289 aa) of the human TSHR. Appropriate cell culture conditions at $27^{\circ} \mathrm{C}$ or $37^{\circ} \mathrm{C}$, respectively, allowed for a relatively more abundant production of either temperature-sensitive or -insensitive TSHR-His proteins. For TSHR-Fc, the production was adapted to flask culture and production at $27^{\circ} \mathrm{C}$ to dominantly produce the temperature-sensitive form (please see Methods).

\section{Characterization of the binding to M22}

In order to characterize the binding of the preparations of TSHR-His to M22, the human anti-TSHR antibody recognizing the active (here temperature-sensitive) form of the extracellular domain, we incubated various concentrations of temperature-sensitive TSHR-His and of conventionally prepared, temperature-insensitive TSHR-His or of TSHR-Fc with the immobilized M22 antibody and detected binding with specific POD antibody conjugates. The binding curves are shown in Fig. 1, which illustrates $\mathrm{EC}_{50}$ values of $0.24 \mu \mathrm{g} / \mathrm{mL}$ (corresponding to $5.7 \mathrm{nmol} / \mathrm{L}$ ) for temperature-sensitive TSHR-His, and of $1.75 \mu \mathrm{g} / \mathrm{mL}$ (corresponding to $42 \mathrm{nmol} / \mathrm{L}$ ) for temperatureinsensitive TSHR-His, and of $0.96 \mu \mathrm{g} / \mathrm{mL}$ (corresponding to $8.6 \mathrm{nmol} / \mathrm{L}$ ) for the temperature-sensitive form of TSHR-Fc used in this study. We also studied a small batch of TSHR-Fc which was incubated at $37^{\circ} \mathrm{C}$ for $24 \mathrm{~h}$ to induce a shift to the predominantly temperature-insensitive form. This affinity of this 'stressed' batch to M22 was $48 \mu \mathrm{g} / \mathrm{mL}$ (430 mmoL/L), and hence, 50-fold lower than the temperature-sensitive form. This batch was studied further by ultracentrifugation.

The comparability of using monoclonal antiHis antibodies to detect TSHR-His versus polyclonal

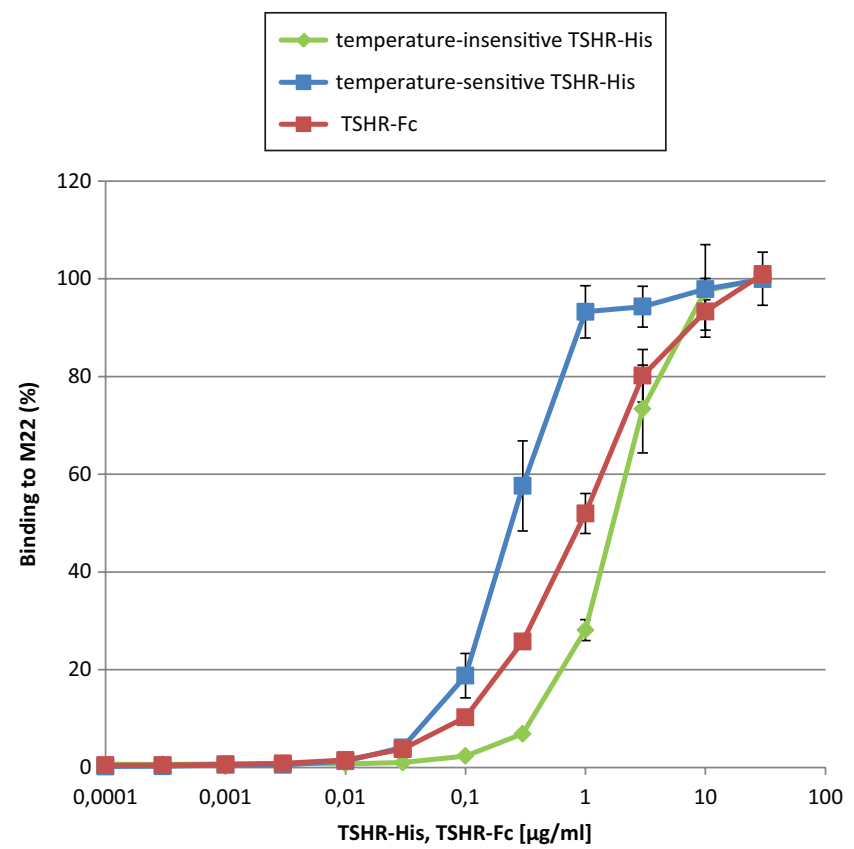

Figure 1

Binding of temperature-sensitive or temperature-insensitive TSHR-His or TSHR-Fc to immobilized anti-TSHR antibody M22. Response curves show the binding capacity of increasing concentrations of temperaturesensitive TSHR-His or TSHR-Fc in comparison to temperature-insensitive TSHR fusion proteins. Means of three independent experiments with S.D. are plotted. A full color version of this figure is available at https://doi. org/10.1530/JOE-20-0061.

anti-TSHR antibodies from TSHR-immunised mice was ascertained by using both in a head-to-head comparison assay for TSHR-His. A direct detection with anti-human Fc antibodies was not possible because of confounding signals elicited by the Fc part of the M22 antibody. The $\mathrm{EC}_{50}$ value of $0.24 \mu \mathrm{g} / \mathrm{mL}$ (corresponding to $5.7 \mathrm{nmol} / \mathrm{L}$ ) for temperature-sensitive TSHR-His determined with the anti-His antibody was comparable to the $\mathrm{EC}_{50}$ determined with the murine polyclonal anti-TSHR antibodies $(0.33 \mu \mathrm{g} / \mathrm{mL}$, corresponding to $7.13 \mathrm{nmol} / \mathrm{L})$.

\section{Functional characterization: Effects of TSHR preparations on human anti-TSHR antibody-induced intracellular CAMP formation}

To determine the functionality of temperature-sensitive and -insensitive TSHR-His and TSHR-Fc, we investigated their ability to inhibit M22-triggered human TSHRmediated intracellular cAMP formation in JP2626 CHO cells, expressing the human TSHR. Figure 2 shows that temperature-sensitive TSHR-His inhibits M22dependent cAMP formation with an $\mathrm{IC}_{50}$ value of $0.84 \mu \mathrm{g} / \mathrm{mL}$ (corresponding to $20 \mathrm{nmol} / \mathrm{L}$ ) in this assay. Higher concentrations of the temperature-insensitive form of TSHR-His were required to obtain the same 


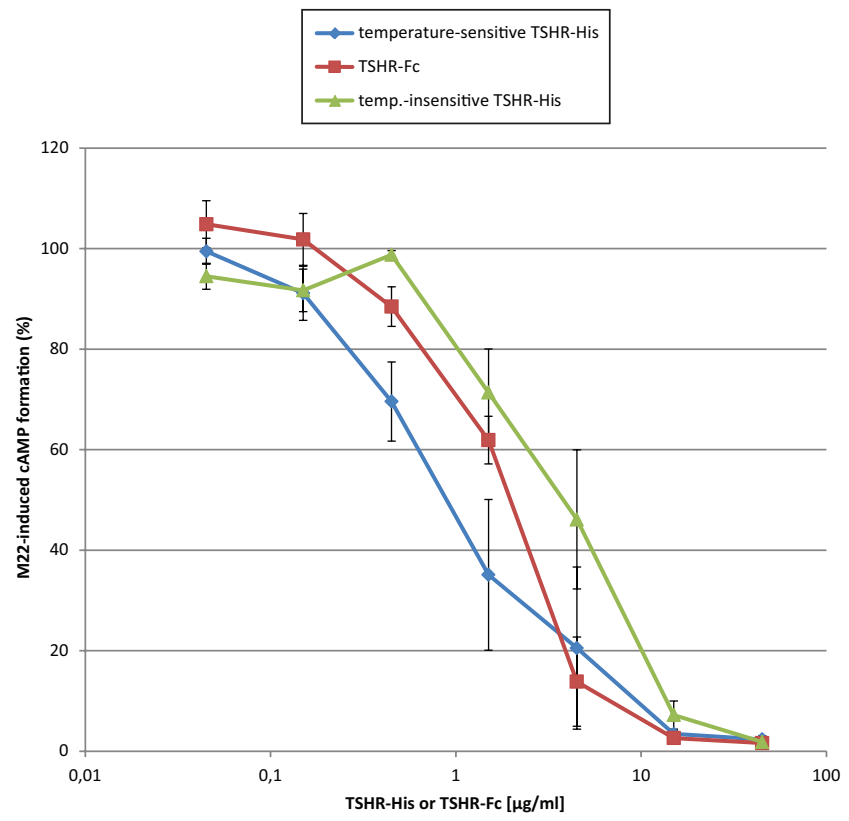

Figure 2

Effects of temperature-sensitive or temperature-insensitive TSHR-His or TSHR-Fc on CAMP formation induced by the monoclonal anti-TSHR antibody M22 in TSHR-expressing test cells. The concentration-dependent effects of temperature-sensitive and -insensitive TSHR-His or TSHR-Fc on intracellular CAMP formation were analyzed in JP2626 CHO cells expressing the human TSHR. TSHR was stimulated with monoclonal anti-TSHR antibody M22 (100 ng/mL final concentration). Concentrationdependent inhibition of the anti-TSHR antibody triggered stimulation of cAMP formation was most effective using temperature-sensitive TSHR-His. Results are shown as means of five experiments with S.E.M. A full colour version of this figure is available at https://doi.org/10.1530/ JOE-20-0061.

inhibitory effect $\left(\mathrm{IC}_{50}\right.$ value of $4.0 \mu \mathrm{g} / \mathrm{mL}$, corresponding to $96 \mathrm{nmol} / \mathrm{L})$. TSHR-Fc resulted in an $\mathrm{IC}_{50}$ value of $1.77 \mu \mathrm{g} / \mathrm{mL}$, corresponding to $16 \mathrm{nmol} / \mathrm{L}$.

\section{Functional characterization in Graves' disease patients' blood samples}

In addition to analyzing the effect on cAMP formation induced by the well-characterized, high-affinity monoclonal anti TSHR antibody M22, we characterized the capacity of the temperature-sensitive TSHR-His and TSHR-Fc to block cAMP formation induced by polyclonal antibodies in the serum of GD patients.

The presence of functionally active anti-TSHR antibodies in the GD patient sera used above was verified by investigating their stimulatory activity as the capacity of human serum samples to induce an increase in TSHRdependent cAMP levels using JP2626 CHO cells. Many of the third generation-identified Graves' patient samples also led to a significant increase in TSHR-dependent cAMP formation above baseline, determined to be $6 \mathrm{pmol}$ cAMP/mLL.

Reassessment of the 48 suspected GD patients by thirdgeneration assay showed that four did not fulfil GD and were therefore used as hyperthyroid, non-GD controls in this study. Of the remaining 44 GD samples, a significant TSHR-dependent cAMP increase above baseline occurred with 32 serum samples in TSHR-expressing test cells. Of these, 30 were inhibited by $25 \%$ or more by maximum concentrations of $100 \mu \mathrm{g} / \mathrm{mL}$ of both, TSHR-His or TSHR-Fc, respectively, corresponding to a response rate of $93 \%$ of both proteins in relation to those samples which elicited TSHR-dependent cAMP formation. Despite the overall broad GD population, an ex vivo effect of TSHRHis or TSHR-Fc was detectable in $70 \%$ of samples (data not shown).

A full characterization of concentration-response curves including $\mathrm{EC}_{50}$ values was done in 10-11 patient samples, which were randomly selected from the available GD serum samples. Figure $3 \mathrm{~A}$ and $\mathrm{B}$ show that both temperature-sensitive TSHR-His and TSHR-Fc are capable to efficiently and dose-dependently reduce the cAMP formation induced by any of 11 Graves' patient sera. For TSHR-His, the $\mathrm{IC}_{50}$-values varied between 0.57 and $13 \mu \mathrm{g} / \mathrm{mL}$, corresponding to a range between 13.7 and $312 \mathrm{nmol} / \mathrm{L}$. For TSHR-Fc, the $\mathrm{IC}_{50}$ values varied between 0.93 and $92 \mu \mathrm{g} / \mathrm{mL}$, corresponding to a range between 8.37 and $828 \mathrm{nmol} / \mathrm{L}$.

Figure 4 shows the mean inhibitory effects of temperature-sensitive TSHR-His or TSHR-Fc on TSHRdependent cAMP formation induced by the 11 and 10 different GD patient serum samples. The resulting $\mathrm{IC}_{50}$ value was determined to be at $2.84 \mu \mathrm{g} / \mathrm{mL}$ (corresponding to $68 \mathrm{nmol} / \mathrm{L}$ ) for TSHR-His and $3.29 \mu \mathrm{g} / \mathrm{mL}$ (corresponding to $29.6 \mathrm{nmol} / \mathrm{L}$ ) for TSHR-Fc by graphical analysis of the mean value curve using SigmaPlot. This value corresponded fairly well to the mean value calculated from individually fitted $\mathrm{IC}_{50}$-values of the single patient curves: for TSHR-Fc: $87 \mathrm{nmol} / \mathrm{L}$, with a 95\% CI of 19-400 $\mathrm{nmol} / \mathrm{L}$; for TSHR-His: $5.6 \mu \mathrm{g} / \mathrm{mL}$, corresponding to 50.6 $\mathrm{nmol} / \mathrm{L}$, with a $95 \% \mathrm{CI}$ of $1.6-1600 \mathrm{nmol} / \mathrm{L}$.

\section{Diagnostic ELISA for the identification of GD patients}

In the previous section, we have shown that temperaturesensitive TSHR His bound/inhibited M22 with low $\mathrm{EC}_{50}-/ \mathrm{IC}_{50}$-values and targeted functional anti-TSHR antibodies. Therefore we considered this protein as a https://joe.bioscientifica.com https://doi.org/10.1530/JOE-20-0061 (c) 2020 Society for Endocrinology Published by Bioscientifica Ltd. 

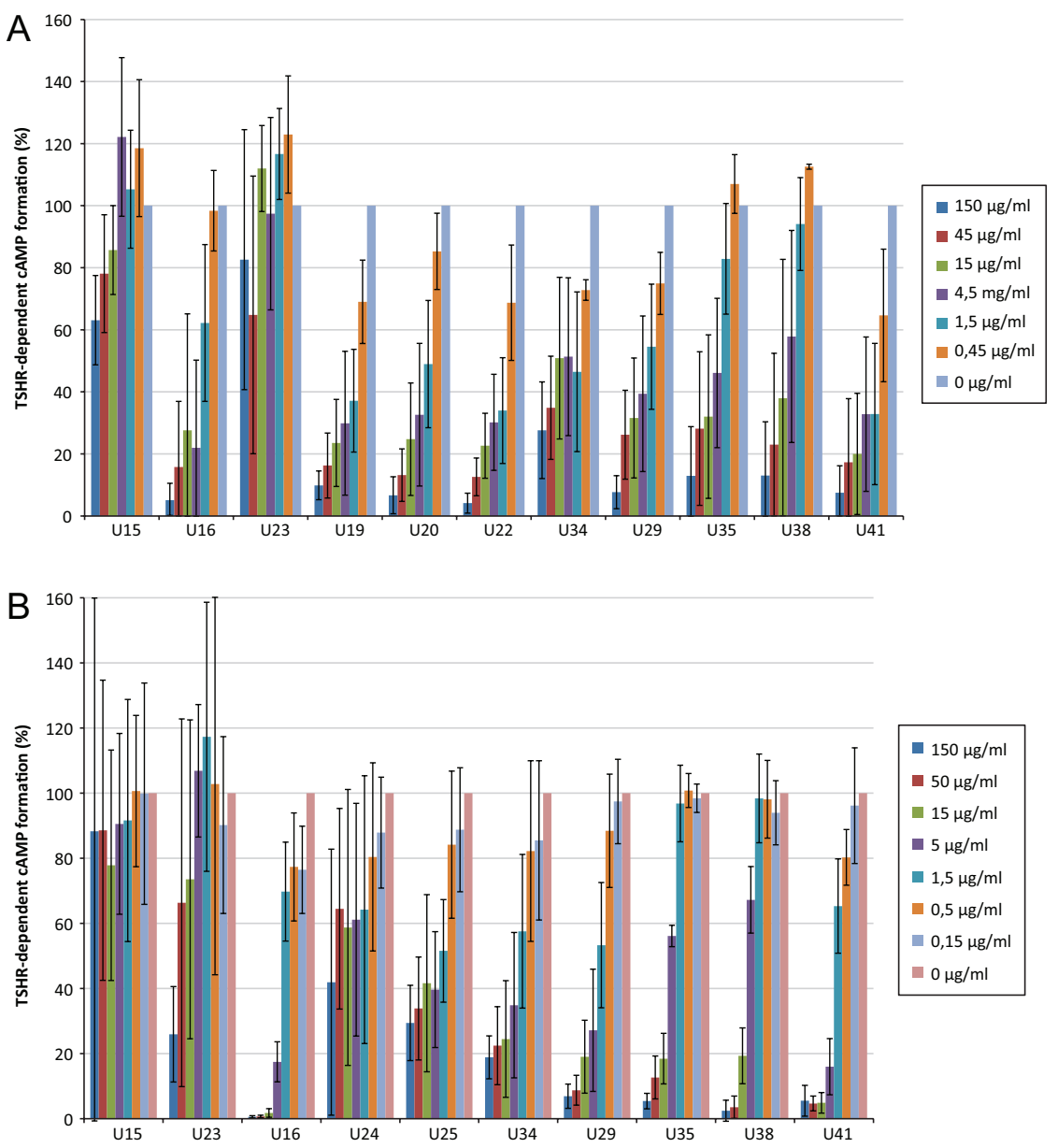

\section{Figure 3}

Effects of temperature-sensitive TSHR-His (A) or TSHR-Fc (B) on CAMP formation induced by Graves' disease patient serum samples containing anti-TSHR antibodies. The concentrationdependent effect of temperature-sensitive TSHR-His or TSHR-Fc on the intracellular CAMP formation was analysed in JP2626 CHO cells expressing the human TSHR. TSHR was stimulated with eleven serum samples from distinct GD patients (diluted 1:5). Codes on $x$ axis indicate individual patients. Results are shown as means of triplicate analyses with S.E.M. A full color version of this figure is available at https://doi. org/10.1530/JOE-20-0061.

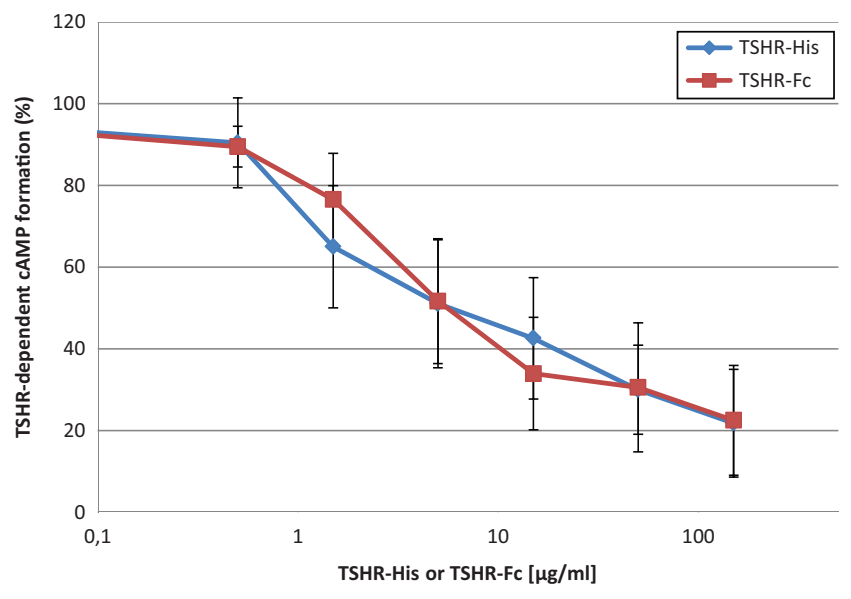

Figure 4

Mean inhibition of anti-TSHR antibody-induced intracellular CAMP expression by TSHR preparations in GD patient samples. Mean values \pm S.E.M. of all 11 investigated GD patient samples: inhibition of anti-TSHR antibody-induced intracellular CAMP levels by temperature-sensitive TSHR-His (blue symbols) or TSHR-Fc (red symbols). A full color version of this figure is available at https://doi.org/10.1530/JOE-20-0061.

(C) 2020 Society for Endocrinology Published by Bioscientifica Ltd. Printed in Great Britain suitable tool to be used as a soluble probe in a competition ELISA, designed to measure anti-TSHR antibody titer from sera of GD patients. In comparison to the third generation assay, this new 'M22-TSHR-His' ELISA format inverted the position of the binding partners (see Fig. 5A for illustration). The human anti-TSHR antibodies from GD patients inhibited the binding of the immobilized human monoclonal thyroid stimulating antibody M22 to the soluble temperature-sensitive TSHR-His protein.

Figure 5B shows the direct comparison of the antiTSHR titres of 41 serum samples from GD patients, 4 control serum samples from (latently) hyperthyroid patients without GD and 17 healthy controls, which were obtained in the third generation assay (with lower sample volumes) and in the new assay format, respectively. In order to ensure comparability, the identical standard samples provided by the third generation assay kit were used in both assays. Sharing the third generation assay cut-off value of $0.4 \mathrm{U} / \mathrm{L}, 96.8 \%$ serum samples were classified consistently - in detail, 39 samples with GD were recognized as positive and all 
A
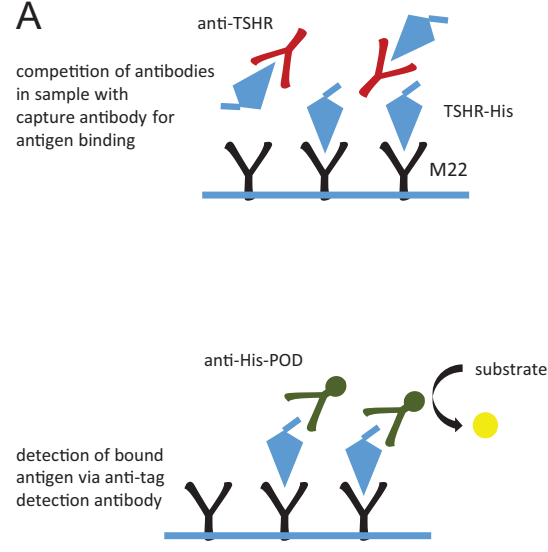

B

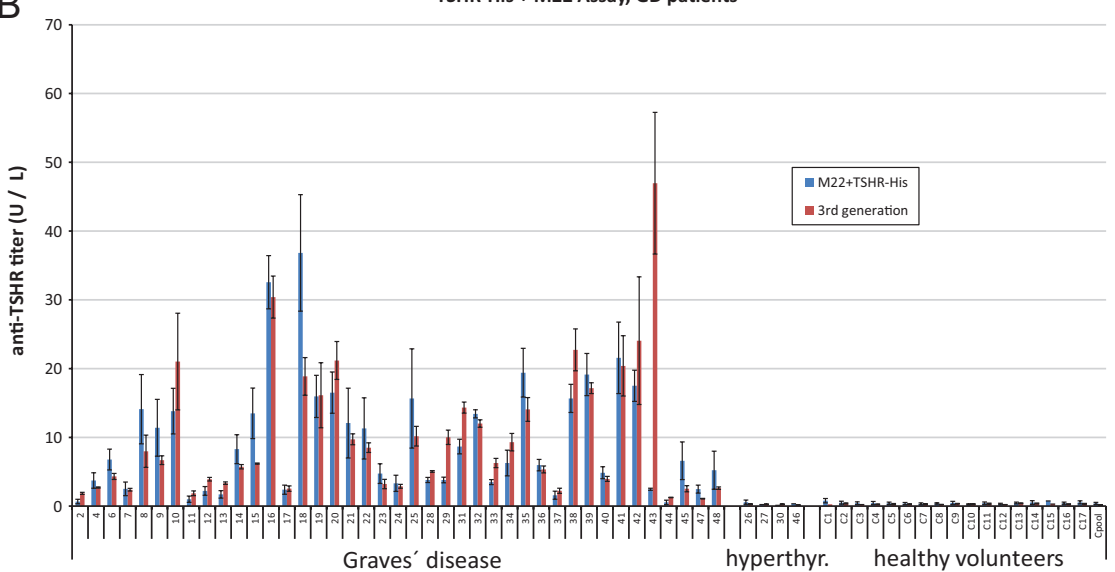

\section{Figure 5}

Comparison of titer values of GD patients measured by third generation assay vs M22-TSHR-His assay. (A) Schematic overview of the novel 'M22 + TSHRHis' ELISA method. (B) The competitive activity of anti-TSHR antibodies was analysed in 41 serum samples of GD patients ('Graves' disease') and 17 control samples of healthy volunteers (C1-C17). 'C Pool' indicates an additional measurement of all C samples together. In addition, four samples of hyperthyroid patients in whom no evidence of Graves' disease was detected served as another control group ('hyperthyroidism'). Each bar represents the mean \pm standard deviation (SD) of duplicate determinations for either the novel 'M22 + TSHR-His' ELISA method (blue bars) or the current gold standard assay ('3rd generation'; red bars). A full color version of this figure is available at https://doi.org/10.1530/JOE-20-0061.

17 control samples of healthy volunteers were recognized as negative. Similarly, four hyperthyroid control patients in whom no evidence of GD was detected were also correctly recognized as negative. The titer values of both assays showed a high consistency. Comparing the values measured in the samples of the same subjects by using the third generation assay and the new assay, the correlation coefficient amounted to $R=0.57$. This ELISA might thus be alternatively used for the determination of TSHR autoantibodies in human serum.

\section{Analysis of TSHR-Fc by ultracentrifugation}

The presence of multimers and monomers of 'stressed' $\left(37^{\circ} \mathrm{C}\right.$ for $\left.24 \mathrm{~h}\right)$ vs unstressed dimeric TSHR-Fc was investigated after ultracentrifugation. The percentage of dimers was very similar after stressed and non-stressed conditions, and after stressing some monomers change to forms with higher molecular weights (data not shown).

\section{Mouse studies in vivo}

Ad-TSHR-immunized mice were randomly assigned to receive epicutaneous patches containing either 0.3 or $0.6 \mathrm{mg} / \mathrm{kg}$ body weight TSHR-Fc or vehicle control. This therapy was started 1 week after the fourth immunization by epicutaneous patches, and then continued at 4-weekly intervals. No animals were prematurely taken out of the study after randomization, and the prespecified protocol was completed in all animals. Results reflect the respective means of all values of all randomized animals in the groups. Tolerability of patches had been tested in a previous pilot study.

\section{Thyroid sizes, as determined from serial sections}

Thyroid volumes $\left(\mathrm{mm}^{3}\right)$ were determined from the sum of the areas of each section over the whole cutting region (between slides 5 and 10, depending on respective size of the thyroid gland) multiplied by the slice thickness of $0.5 \mathrm{~mm}$. This macroscopic investigation showed clearly increased thyroid sizes in mice which had received nine immunizations of Ad-TSHR289 (Fig. 6), compared to the healthy and GFP-immunized control groups. There was no statistically significant difference of thyroid sizes between Ad-TSHR-immunized mice exposed to epicutaneous TSHR-Fc and untreated controls.

\section{Determination of thyroxin serum levels}

Thyroxin (T4) levels did not differ between groups at study start, and mean T4 levels in eligible animals of the Ad-TSHR289-immunized groups were significantly higher than controls at week 11 (start of therapy, Fig. 7), and exceeded the normal T4 value range, which was defined as $5,97-6.81 \mu \mathrm{g} / \mathrm{dL}$ in our laboratory (means \pm 2 s.e. of control mice). There was no statistically significant difference of T4 values between Ad-TSHR-immunized mice exposed to epicutaneous TSHR-Fc and untreated controls. 


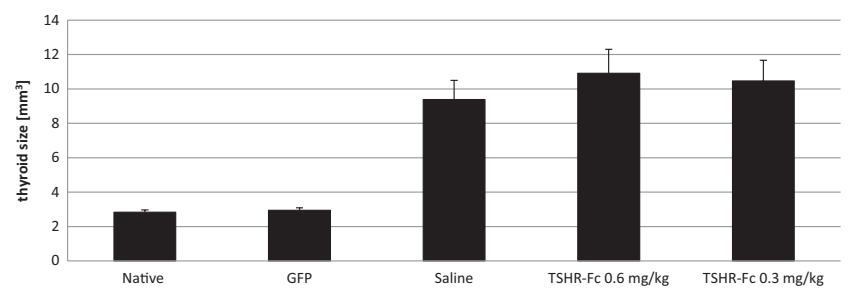

Figure 6

Effects on macroscopically measured thyroid size. The effects of the TSHR-Fc fusion protein on thyroid sizes were investigated at the end of the experiment. The measurements were carried out in Ad-TSHRimmunized mice treated by either 4-weekly epicutaneous patch administrations of vehicle $(0.9 \% \mathrm{NaCl}$, 'saline', $n=12$ mice), or administrations of $0.3 \mathrm{mg} / \mathrm{kg}$ (12 mice) or $0.6 \mathrm{mg} / \mathrm{kg}$ body weight (11 mice) of TSHR-Fc. In addition, Ad-GFP-immunized control mice ('GFP, $n=5$ mice) and age-matched immunologically naïve unimmunized mice (native', 5 animals) were investigated. The mean thyroid sizes $\left(\mathrm{mm}^{3}\right)$ are shown with S.E.M. There were no significant differences between Ad-TSHR-immunized groups as determined by AVOVA testing.

\section{ECG to determine heart rates}

Starting from the third immunization, a significant increase in heart rate in the hyperthyroid Ad-TSHR289 immunized group was observed (Fig. 8). In contrast, heart rate in the native, healthy group or in the GFP immunized control group was only mildly increased at older age, but did not change significantly.

Upon consecutive Ad-TSHR289-immunizations, a further strong increase in heart rate in the hyperthyroid vehicle-treated group was observed. There was no statistically significant difference of heart rate between Ad-TSHR-immunized mice exposed to epicutaneous TSHR-Fc and untreated controls.

\section{Anti-TSHR antibody titers}

Anti-TSHR antibodies were determined from serum samples by investigating the ability of the respective mouse sera to inhibit the binding of the monoclonal Graves' patient antibody M22 to the TSHR ('3rd generation ELISA). High titers were detected in all Ad-TSHR289-immunized animals (Fig. 9). There was no statistically significant difference of anti-TSHR antibody titers between Ad-TSHR-immunized mice exposed to epicutaneous TSHR-Fc and untreated controls, but the TSHR-Fc-treated groups trended to develop even higher titers than the control group.

\section{Discussion}

This manuscript characterizes the $\mathrm{EC}_{50^{-}}$and $\mathrm{IC}_{50^{-}}$-values of temperature-sensitive forms of TSHR A domain fusion proteins - His-tagged TSHR and TSHR-Fc - based on measurements of concentration-dependent binding and functional effects on anti-TSHR antibodies. We show that $\mathrm{IC}_{50}$ values to inhibit monoclonal M22-dependent cAMP formation of either His-tagged TSHR (which contains only one TSHR A domain) or an TSHR-Fc fusion protein (which contains two TSHR A domains at relatively fixed steric orientation) are observed at lower nanomolar concentrations. In addition, both proteins inhibit cAMP formation induced by various Graves' patient sera at similar concentrations. However, epicutaneous administration of one of these fusion proteins, TSHR-Fc, did not improve Graves' disease parameters in a long-term mouse model.

Chazenbalk et al. (2001) had shown effects of a similar TSHR construct at a maximum concentration which was comparable to our results. The high efficiencies of both, the temperature-sensitive His-tagged TSHR and TSHR-Fc in blocking the anti-TSHR antibody-induced stimulation of the TSHR might not only qualify the proteins as soluble probes, but also as potential anti-TSHR antibody scavengers or immune modulating agents in vivo.

Both proteins react with autoantibodies of blood samples of a large majority of GD patients. Out of a study

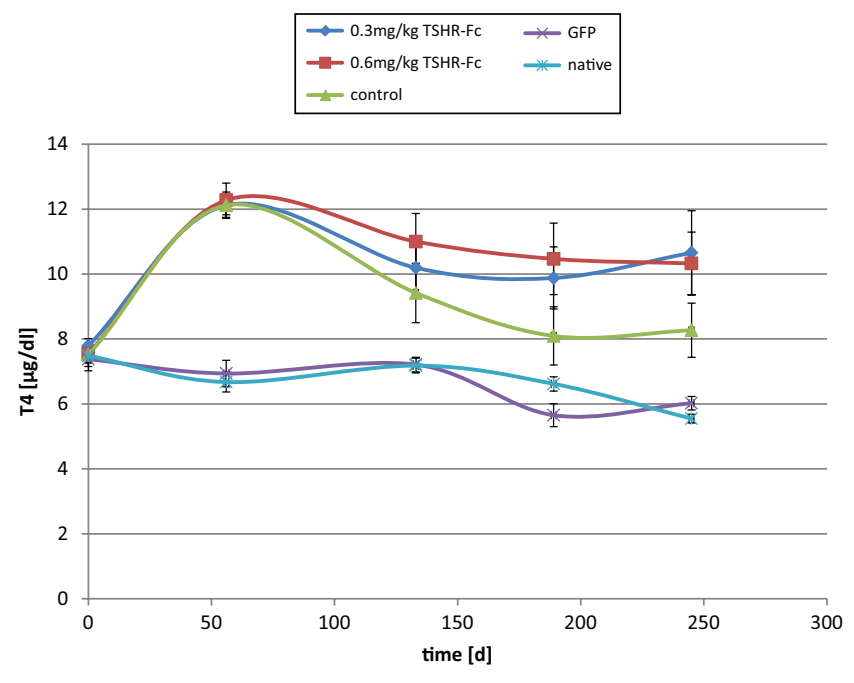

Figure 7

Effect on serum thyroxin (T4) levels. The effects the TSHR-Fc fusion protein on serum thyroxin levels were evaluated. The measurements were carried out in serum samples of Ad-TSHR-immunized mice treated by either 4-weekly epicutaneous patch administrations of vehicle $(0.9 \% \mathrm{NaCl}$, 'saline, $n=12$ mice), or administrations of $0.3 \mathrm{mg} / \mathrm{kg}$ (12 mice) or $0.6 \mathrm{mg} / \mathrm{kg}$ body weight (11 mice) of TSHR-Fc. In addition, Ad-GFPimmunized control mice ('GFP', $n=5$ mice) and age-matched immunologically naïve unimmunized mice ('native', 5 animals) were investigated. Data are represented as means \pm S.E.M. There were no significant differences between Ad-TSHR-immunized groups compared to the untreated control as determined by AVOVA testing. A full color version of this figure is available at https://doi.org/10.1530/JOE-20-0061. 


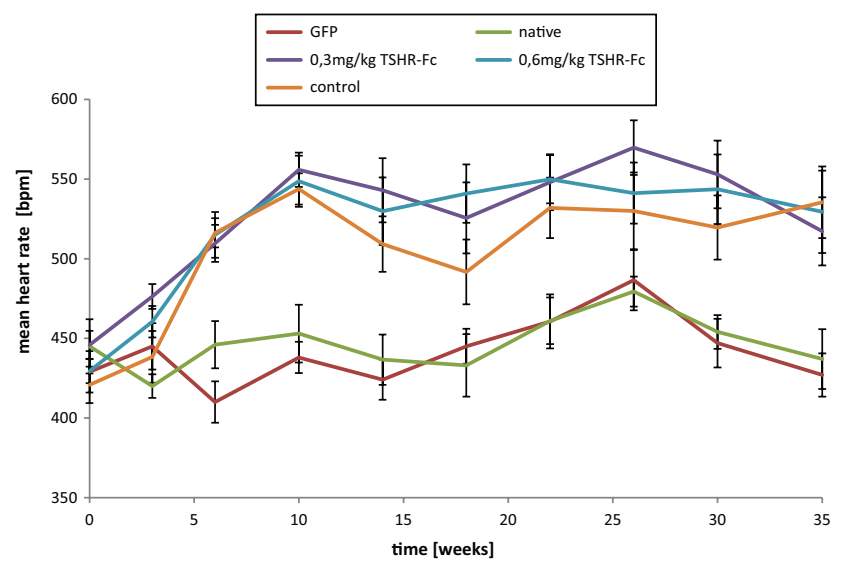

\section{Figure 8}

Effect on heart rates. The effects the TSHR-Fc fusion protein on heart rates at various times were evaluated in all animals. The measurements were carried out in Ad-TSHR-immunized mice treated by either 4-weekly epicutaneous patch administrations of vehicle $(0.9 \% \mathrm{NaCl}$, 'saline, $n=12$ mice), or administrations of $0.3 \mathrm{mg} / \mathrm{kg}$ (12 mice) or $0.6 \mathrm{mg} / \mathrm{kg}$ body weight (11 mice) of TSHR-Fc. In addition, Ad-GFP-immunized control mice ('GFP' , $n=5$ mice) and age-matched immunologically naïve unimmunized mice ('native, 5 animals) were investigated. Data are represented as mean \pm S.E.M. There were no significant differences between Ad-TSHR-immunized groups as determined by AVOVA testing. A full color version of this figure is available at https://doi.org/10.1530/JOE-20-0061.

population of 44 reconfirmed GD patients, 32 serum samples elicited measureable cAMP formation - almost all of these showed significantly decreased TSHR-dependent cAMP formation upon exposure to either $100 \mu \mathrm{g} / \mathrm{mL}$ TSHR-His or TSHR-Fc.

Generally, the described assays and compounds are based on previous reports on preparations of the TSHR A-subunit, which can be purified from overexpressing cell culture supernatants in two different forms. The temperature-sensitive ('active') form neutralized the TSH binding inhibitory activity of Graves' sera, whereas the temperature-insensitive ('inactive') form was not reactive with sera from Graves' patients (Chazenbalk et al. 1999, 2001, Schwarz-Lauer et al. 2002). Based on their crystal structures, M22 (Sanders et al. 2007) and 3BD10 (Chen et al. 2015) should be able to bind simultaneously to the monomeric form of the TSHR A-subunit. Chen et al. (2015) thus concluded that the monomeric A-subunit cannot explain the reciprocally exclusive anti-TSHR antibody/ M22 and 3BD10 binding, but instead hypothesized that TSHR-stimulating antibodies and 3BD10 bind to A-subunit multimers with different quaternary structure/valency. In silico analyses of the group suggested that stimulatory anti-TSHR antibodies bind to trimers, whereas 3BD10 binds to dimers (Chen et al. 2015).

Rapoport et al. (2015) picked up this concept and systematically (re)investigated the binding characteristics of sera from Graves' patients and from mice that developed hyperthyroidism due to repeated immunizations with TSHR A-subunit-expressing adenovirus. The group confirmed earlier results that pathologic sera from Graves' patients inhibited binding of TSH to temperaturesensitive TSHR, but only rarely bound to the temperatureinsensitive TSHR A-subunit. They further showed that sera of hyperthyroid mice recognized both forms of the TSHR A-subunit, and concluded that pathogenic autoantibody affinity maturation in Graves' disease is probably driven by A-subunit multimers, not monomers.

Our analysis of the (dimeric) temperature-sensitive TSHR-Fc fusion protein showed that this dimeric protein occurs mainly as such in solution, but partly assembles spontaneously into dimers of these dimers. Stressing conditions do not have an impact on this condition, but impact on binding to the antibody M22, so that at least with the very active and high-affinity binding TSHR-Fc, the hypothesis of Rapoport et al. (2015) about the importance of trimers versus dimers does not seem to be relevant. Our approach, however, is limited by the following considerations: The fixed orientation of two A-subunits attached to an Fc is not exactly like the random association

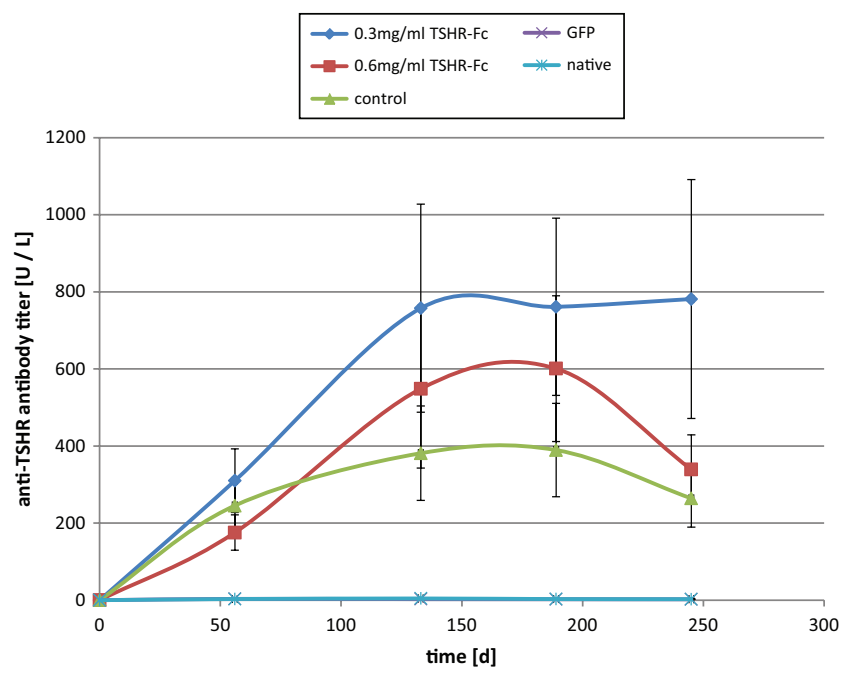

Figure 9

Effect on anti-TSHR antibody titers. The effect of the TSHR-Fc fusion protein on time course of anti-TSHR titers, as measured by third generation ELISA, in which serum samples are used to determine inhibition of M22-binding to coated plates. The measurements were carried out in Ad-TSHR-immunized mice treated by either 4-weekly epicutaneous patch administrations of vehicle $(0.9 \% \mathrm{NaCl}$, 'saline', $n=12$ mice), or administrations of $0.3 \mathrm{mg} / \mathrm{kg}$ (12 mice) or $0.6 \mathrm{mg} / \mathrm{kg}$ body weight (11 mice) of TSHR-Fc. In addition, Ad-GFP-immunized control mice ('GFP', $n=5$ mice) and age-matched immunologically naïve unimmunized mice ('native, 5 animals) were investigated. Data are represented as mean \pm S.E.M. There were no significant differences between Ad-TSHR-immunized groups as determined by AVOVA testing. A full color version of this figure is available at https://doi.org/10.1530/JOE-20-0061. 
of free, unattached A-subunits. Also, temperature-sensitive TSHR fusions may represent a mixture of active and inactive forms: their amounts required to fully neutralize anti-TSHR-antibodies (Fig. 3) were higher than those required by purified active A-subunits (Chazenbalk et al. 2001) - some of the preparations may therefore be inactive. The temperature-insensitive TSHR-His preparation contained conformations that are still recognized by anti-TSHR antibodies specific for the 'immunologically active' conformation (M22 and autoantibodies of the GD sera) (Figs 1 and 2), whereas purified inactive A-subunits were not recognized by these antibodies (Chazenbalk et al. 2001).

Our results show that a high affinity interaction of TSHR A subunit with the anti-TSHR antibody M22 occurs, regardless if it is C-terminally extended with a His tag or dimerized via Fc.

In comparison to the gold standard third generation assay (Smith et al. 2004), we established a new ELISA format which inverts the position of the binding partners. The human anti-TSHR antibodies from GD patients inhibit the binding of the immobilized human monoclonal thyroid stimulating antibody M22 to the soluble temperaturesensitive TSHR-His protein. This assay configuration avoids the highly challenging purification procedure of the membrane-bound TSHR protein. A second beneficial effect is that the minimal serum volume is reduced to $8 \%$ of that used in the third generation assay.

It had been known before that addition of nanogram quantities of the temperature-sensitive TSHR A domain to Graves sera can fully neutralize the 125I-TSH binding inhibition (Chazenbalk et al. 1999, Rapoport et al. 2015), anti-TSHR antibodies (Chazenbalk et al. 2002) and M22-induced intracellular cAMP formation (Mizutori et al. 2009).

Here, we show and reconfirm that the temperaturesensitive form of His-tagged TSHR inhibits M22 binding to TSHR and human Graves' serum-induced TSHRdependent cAMP induction in test cells at nanomolar $\mathrm{IC}_{50}$ values. In addition, we show that this is also true for temperature-sensitive form of a TSHR-Fc fusion protein which expresses two TSHR A domains at a fixed steric conformation.

However, epicutaneous administration of TSHR-Fc did not result in any beneficial effect on a long-term disease model in vivo. The results of this study partially corroborate those after repeated i.v. administration of a fusion protein of the TSHR A domain with Fc in immunologically naïve mice: 2 animals developed antiTSHR titers after treatment with $1 \mathrm{mg} / \mathrm{kg}$ TSHR-Fc, and suffered from signs of allergy (Holthoff et al. 2017). These findings are in line with those after single administration of TSHR A domain (Misharin et al. 2009) or 4-fold administration of a nanoparticle-coated TSHR A domain (McLachlan et al. 2019) in Graves' mouse models, but are in contrast to those obtained after administration of TSHR-derived cyclic peptides, which did not induce any immune response and can re-establish tolerance toward the antigen in immunized mice (Holthoff et al. 2017, Faßbender et al. 2019), improving symptoms of GD within 3-4 months after starting these therapies.

As another antigen-specific therapy to induce tolerance to the TSHR in patients with GD, T cell epitopederived linear peptides have also been identified using immunized HLA-DR3 transgenic mice (Jansson et al. 2016, 2018). A combination of such peptides (Jansson et al. 2018) has yielded promising results in a first clinical trial in patients with GD (Pearce et al. 2019).

In summary, despite high affinity to bind to Graves' patients anti-TSHR auto-antibodies, epicutaneous administration of TSHR-Fc did not exert a beneficial effect on hyperthyroidism, tachycardia and other in vivo read-outs in a long-term mouse model of Graves' disease induced by immunization with a recombinant adenovirus encoding TSHR A in mice in vivo. These results should therefore guide further clinical development of antigenspecific therapies of the disease. They rather discourage to use the full Graves' auto-antigen to achieve this goal.

\section{Declaration of interest}

The authors declare that there is no conflict of interest that could be perceived as prejudicing the impartiality of the research reported. Four of the five authors are employed by the biotech company advanceCOR $\mathrm{GmbH}$.

\section{Funding}

This research did not receive any specific grant from any funding agency in the public, commercial or not-for-profit sector.

\section{References}

Bahn RS 2010 Graves' opthalmopathy. New England Journal of Medicine 362 726-738. (https://doi.org/10.1056/NEJMra0905750)

Bynoe MS, Evans JT, Viret C \& Janeway Jr CA 2003 Epicutaneous immunization with autoantigenic peptides induces T suppressor cells that prevent experimental allergic encephalomyelitis. Immunity 19 317-328. (https://doi.org/10.1016/s1074-7613(03)00239-5)

Chazenbalk GD, Wang Y, Guo J, Hutchison JS, Segal D, Jaume JC, McLachlan SM \& Rapoport B 1999 A mouse monoclonal antibody 
to a thyrotropin receptor ectodomain variant provides insight into the exquisite antigenic conformational requirement, epitopes and in vivo concentration of human autoantibodies. Journal of Clinical Endocrinology and Metabolism 84 702-710. (https://doi.org/10.1210/ jcem.84.2.5481)

Chazenbalk GD, McLachlan SM, Pichurin P, Yan XM \& Rapoport B 2001 A prion-like shift between two conformational forms of a recombinant thyrotropin receptor A-subunit module: purification and stabilization using chemical chaperones of the form reactive with Graves' autoantibodies. Journal of Clinical Endocrinology and Metabolism 86 1287-1293. (https://doi.org/10.1210/jcem.86.3.7363)

Chazenbalk GD, Pichurin P, Chen CR, Latrofa F, Johnstone AP, McLachlan SM \& Rapoport B 2002 Thyroid-stimulating autoantibodies in Graves' disease preferentially recognize the free A subunit, not the thyrotropin holoreceptor. Journal of Clinical Investigation 110 209-217. (https://doi.org/10.1172/JCI15745)

Chen CR, Pichurin P, Nagayama Y, Latrofa F, Rapoport B \& McLachlan SM 2003 The thyrotropin receptor autoantigen in Graves' disease is the culprit as well as the victim. Journal of Clinical Investigation $\mathbf{1 1 1}$ 1897-1904. (https://doi.org/10.1172/JCI17069)

Chen CR, Hubbard PA, Salazar LM, McLachlan SM, Murali R \& Rapoport B 2015 Crystal structure of a TSH Receptor monoclonal antibody: insight into Graves' disease pathogenesis. Molecular Endocrinology 29 99-107. (https://doi.org/10.1210/me.2014-1257)

Faßbender J, Holthoff HP, Li Z \& Ungerer M 2019 Therapeutic effects of short cyclic and combined epitope peptides in a long-term model of Graves' disease and orbitopathy. Thyroid 29 258-267. (https://doi. org/10.1089/thy.2018.0326)

Frank CU, Braeth S, Dietrich JW, Wanjura D \& Loos U 2015 Bridge Technology with TSH receptor chimera for sensitive direct detection of TSHR antibodies causing Graves' disease: analytical and clinical evaluation. Hormone and Metabolic Research 47 880-888. (https://doi. org/10.1055.org/s-0035-1554662)

Hamidi S, Chen CR, Murali R, McLachlan SM \& Rapoport B 2013 Probing structural variability at the $\mathrm{N}$ terminus of the TSH Receptor with a murine monoclonal antibody that distinguishes between two receptor conformational forms. Endocrinology 154 562-571. (https://doi. org/10.1210/en.2012-1822)

Holthoff HP, Göbel S, Li ZM, Fassbender J, Reimann A, Zeibig S, Lohse MJ, Münch G \& Ungerer M 2015 Prolonged TSH receptor A subunit immunization of female mice leads to a long-term model of Graves' disease, tachycardia and cardiac hypertrophy. Endocrinology 156 1577-1589. (https://doi.org/10.1210/en.2014-1813)

Holthoff HP, Li ZM, Fassbender J, Reimann A, Adler K, Münch G \& Ungerer M 2017 Cyclic peptides for effective treatment in a longterm model of Graves' disease and orbitopathy in female mice. Endocrinology 158 2376-2390. (https://doi.org/10.1210/en.2016-1845)

Jansson L, Martin K, Wraith DC, Jahraus A \& Vrolix K 2016 Composition which comprises peptides derived from TSHR. Patent application WO 2016/103213. Geneva, Switzerland: World Intellectual Property Organization.

Jansson L, Vrolix K, Jahraus A, Martin KF \& Wraith DC 2018 Immunotherapy with apitopes blocks immune response to TSH receptor in HLA-DR transgenic mice. Endocrinology 159 3446-3457. (https://doi.org/10.1210/en.2018-00306)
McLachlan SM, Aliesky HA \& Rapoport B 2019 Nanoparticles bearing TSH receptor protein and a tolerogenic molecule do not induce immune tolerance but exacerbate thyroid autoimmunity in hTSHR/NOD.H2h4 mice. Journal of Immunology 202 2570-2577. (https://doi.org/10.4049/ jimmunol.1900038)

Miller-Gallacher J, Sanders P, Young S, Sullivan A, Baker S, Reddington SC, Clue M, Kabelis K, Clark J, Wilmot J, et al. 2019 Crystal structure of a ligand-free stable TSH receptor leucine-rich repeat domain. Journal of Molecular Endocrinology 62 117-128. (https://doi.org/10.1530/JME18-0213)

Misharin AV, Nagayama Y, Aliesky HA, Mizutori Y, Rapoport B \& McLachlan SM 2009 Attenuation of induced hyperthyroidism in mice by pretreatment with thyrotropin receptor protein: deviation of thyroid-stimulating to nonfunctional antibodies. Endocrinology 150 3944-3952. (https://doi.org/10.1210/en.2009-0181)

Mizutori Y, Chen CR, Latrofa F, McLachlan SM \& Rapoport B 2009 Evidence that shed thyrotropin receptor A subunits drive affinity maturation of autoantibodies causing Graves' disease. Journal of Clinical Endocrinology and Metabolism 94 927-935. (https://doi. org/10.1210/jc.2008-2134)

Pearce SHS, Dayan C, Wraith DC, Barrell K, Olive N, Jansson L, WalkerSmith T, Carnegie C, Martin KF, Boelaert K, et al. 2019 Antigenspecific immunotherapy with thyrotropin receptor peptides in Graves' hyperthyroidism: a phase I study. Thyroid 29 1003-1011. (https://doi. org/10.1089/thy.2019.0036)

Rapoport B, Aliesky HA, Chen CR \& McLachlan SM 2015 Evidence that TSH Receptor A-subunit multimers, not monomers, drive antibody affinity maturation in Graves' disease. Journal of Clinical Endocrinology and Metabolism 100 E871-E875. (https://doi.org/10.1210/jc.2015-1528)

Ross DS 2011 Radioiodine therapy for hyperthyroidism. New England Journal of Medicine 364 542-550. (https://doi.org/10.1056/ NEJMct1007101)

Sanders J, Chirgadze DY, Sanders P, Baker S, Sullivan A, Bhardwaja A, Bolton J, Reeve M, Nakatake N, Evans M, et al. 2007 Crystal structure of the TSH receptor in complex with a thyroid-stimulating autoantibody. Thyroid 17 395-410. (https://doi.org/10.1089/thy.2007.0034)

Schwarz-Lauer L, Chazenbalk GD, McLachlan SM, Ochi Y, Nagayama Y \& Rapoport B 2002 Evidence for a simplified view of autoantibody interactions with the thyrotropin receptor. Thyroid 12 115-120. (https://doi.org/10.1089/105072502753522347)

Smith TJ \& Hegedüs L 2016 Graves' disease. New England Journal of Medicine 375 1552-1565. (https://doi.org/10.1056/NEJMra1510030)

Smith BR, Bolton J, Young S, Collyer A, Weeden A, Bradbury J, Weightman D, Perros P, Sanders J \& Furmaniak J 2004 A new assay for thyrotropin receptor autoantibodies. Thyroid 14 830-835. (https:// doi.org/10.1089/thy.2004.14.830)

Walczak A, Siger M, Ciach A, Szczepanik M \& Selmaj K 2013 Transdermal application of myelin peptides in multiple sclerosis treatment. JAMA Neurology 70 1105-1109. (https://doi.org/10.1001/ jamaneurol.2013.3022)

Weetman AP 2000 Graves' disease. New England Journal of Medicine 343 1236-1248. (https://doi.org/10.1056/NEJM200010263431707)

Wildner P \& Selmaj KW 2017 Multiple sclerosis: skin-induced antigenspecific immune tolerance. Journal of Neuroimmunology 311 49-58. (https://doi.org/10.1016/j.jneuroim.2017.08.001)

Received in final form 2 April 2020

Accepted 21 May 2020

Accepted Manuscript published online 21 May 2020 https://joe.bioscientifica.com https://doi.org/10.1530/JOE-20-0061
(C) 2020 Society for Endocrinology Published by Bioscientifica Ltd. Printed in Great Britain 